Article

\title{
Designing a Model to Display the Relation between Social Vulnerability and Anthropogenic Risk of Wildfires in Galicia, Spain
}

\author{
Jaime de Diego ${ }^{1, *(\mathbb{D}}$, Antonio Rúa ${ }^{2}$ and Mercedes Fernández ${ }^{1}$ (i) \\ 1 University Institute of Studies on Migration, Comillas Pontifical University, 28015 Madrid, Spain; \\ mercedes@comillas.edu \\ 2 Faculty of Economics and Business Administration, Comillas Pontifical University, 28105 Madrid, Spain; \\ rvieites@icade.comillas.edu \\ * Correspondence: jdediego@comillas.edu
}

Received: 14 January 2019; Accepted: 6 March 2019; Published: 12 March 2019

\begin{abstract}
Since the beginning of the 21st century, most of the forest fires that have occured in Spain have taken place in the northern region of Galicia. This area represents $5.8 \%$ of the Spanish territory, but compromises, in certain years, up to $50 \%$ of the total number of wildfires. Current research on forest fires is focused mostly on physical or meteorological characteristics, post-fire situations, and their potential destructive capacities (main areas burnt, type of vegetation, economic loses, etc.). However, the academic research to date has not delved into other socioeconomic factors (population structure, density, livestock farms, education, among others), which compromise the existing pre-fire situation in the affected territories, and subsequently reflect the prevailing vulnerability of the population. Indeed, these socioeconomic variables can influence fire occurrence, whether positively or negatively. To fill in this knowledge gap, this article analyzes the relationship between wildfire events and the socioeconomic variables that characterize the Galician municipalities affected. To that effect, first, a thorough examination and selection of the most relevant socioeconomic variables, and their subsequent justification will be carried out. Then, using IBM SPSS statistics 24, a linear regression is executed using the data of wildfires that occurred in Galicia between 2001-2015. The resulting model allows a better knowledge of the importance of the socioeconomic situation in Galician municipalities when wildfires occur. Therefore, this result identifies the existing relationship between the socioeconomic variables and wildfire events, and consequently will help to optimize the interventions that must be done. This may be the best way to carry out prevention actions in order to reduce vulnerability to forest fires.
\end{abstract}

Keywords: socioeconomic variables; Spain; Galicia; wildfires; multiple linear regression

\section{Introduction}

Forest fires are natural disasters that are mostly associated with countries that have specific climatic characteristics and fire-prone vegetation. Spain is situated within the list of countries annually affected by these events together with the United States (US) and Australia. Moreover, in the United States, forest fires have increased their size and destructive potential [1]. In Australia, in the last century, grassland fires have been the fourth risk associated with catastrophes, after heatwaves [2]. Even though it is considered as a natural disaster, the origin of forest fires is usually of human cause, which is around $96 \%$ in the case of Spain [3].

As pointed out in Section 2.1 of this paper, the current research on forest fires mostly focuses on physical or meteorological characteristics, post-fire situations, and their potential destructive capacities 
(main areas burnt, type of vegetation, economic losses, etc.). However, the academic research has not delved into the other socioeconomic factors (population structure, density, livestock farms, education, among others), that configure the existing pre-fire situation in the affected territories, and subsequently reflect a prevailing population vulnerability. Therefore, taking into account the characteristics of the existing population is crucial within the research on forest fires [4].

This perspective is taken from firefighting, which has globally emphasized post-fire actions, without giving priority to prevention efforts and action before a wildfire [5]. Hence, as a fundamental aspect in prevention, it is necessary to know the variables that influence the characteristics of social groups within environments where fires occur, in order to reduce the impacts and occurrence of forest fires [6]. Also, if we focus on Spain, this situation can be observed when analyzing the current legislation about forest fires: the action against wildfires is transferred to the emergency plans, which are emphasized in post-fire situations [7].

Although forest fires are a natural component and necessary within the ecological cycle of certain ecosystems, often, different variables such as the weather or existing populations alter natural fire patterns. This may modify the negative effects of fire so much that the positive consequences that could contribute to the ecosystem are bypassed [8]. In fact, variables such as unequal social and economic structure, where class, ethnicity, sex, and poverty factor in, are very relevant for determining and predicting the occurrence of wildfires.

The Autonomous Community of Galicia has been the Spanish region with the highest number of forest fires in the 21st century. According to the specialized studies quoted in Section 2.2 (Galicia, social vulnerability, and wildfires), forest fires in Galicia might be directly related to a mixture of socioeconomic factors (such as population aging or low population density among with low economic development) and natural or environmental factors (such as extensive livestock farming, abandoned areas, or urban-forest interface areas).

All these factors mean that forest fires, year after year, continue occurring in Galicia, and the measures that have been taken do not seem to be enough for a problem of this magnitude. The situation described in Galicia reinforces the objective of investigating the connection between socioeconomic variables and forest fires in Galicia and, specifically, to find out which variables have the greatest weight.

The aim of this article is to establish the relationship between the socioeconomic aspects that reflect the reality of Galician municipalities and the number of forest fires that have occurred between 2001-2015, and to know which variables carry the greatest weight. A multiple linear regression model, estimated by ordinary least squares (OLS) method, was used to perform this analysis. The observational unit was the municipalities, since it was the smallest unit of information related to wildfires; in addition, it is the minimum territorial unit for which precise and uniform socioeconomic information exists. The model was firstly carried out for all of the municipalities of Galicia. Secondly, with the purpose of analyzing its structural stability, the model was run separately in the municipalities of each province. Finally, to determine if there were differences between provinces, Chow test was executed for the northern region (A Coruña and Lugo), the southern region (Ourense and Pontevedra), and within each region to compare each pair of provinces. This analysis offers action guidelines for the authorities in matters of prevention and awareness.

\section{Materials and Methods}

\subsection{Social Vulnerability and Wildfires}

The qualities that make a natural event a disaster are determined by the territory and the population within the exposed areas. To demarcate risks seems complicated because of this variability [9]. Disasters present multiple dimensions that can be classified as follows [10]:

- Social and population dimension: Includes aspects such as justice, social differences, and social organization and individual strengths. Some studies have incorporated variables such as poverty, 
social marginalization, demographics (age vulnerable groups), education, health and welfare, migration, and risk perception [11]. The factors that determine this dimension are influenced by specific conditions and are very different development processes, depending on the country or region and the kind of danger faced [12].

- Economic dimension: Deals with occupation, income, economic effects, consumption, property, and savings [13]. This dimension also contemplates housing and habitability issues together with livelihood, which may be an aspect to consider in cases where it is based on a single sector (agriculture, fisheries, etc.) [14].

- Environmental or territorial dimension: Even though the environment is the source of the natural processes that can cause a disaster, it is at the same time an important resource for people who have a high hazard exposure [15]. This dimension is related to the environmental destruction effects that cause changes in the natural ecosystem at different scales (melting, destruction of natural barriers in coasts, emissions, etc.) [16]. Therefore, this dimension examines both the population dependence to certain environmental services, and the sensitivity of these environmental services to certain hazards [17].

Social groups with certain characteristics of social vulnerability have a higher risk of suffering the effects of a disaster [18]. The socioeconomic features of a person (such as class, ethnicity, gender, and poverty) or a group of people (unequal social or economic structure) influence their ability to anticipate, cope with, resist, and recover from the impact of a natural disaster $[19,20]$. People in social disadvantage are more likely to suffer from scenarios that worsen their already adverse situation [21].

Within a natural disaster, such as forest fires, certain social, economic and political processes come into play; so, preventive actions should be targeted to people's characteristics. This reinforces the idea of studying the population's peculiarities in the analysis of forest fire risk rather than just looking at the post-disaster effects [22].

Vulnerable social groups become the main victims of forest fires. Nevertheless, individuals can play different roles [23]:

- Vulnerable to fire danger: Any individual or element to be affected by a wildfire.

- Generators of fire risk: They are the source of fire hazard by inappropriate use of the forest, traditional practices, negligence, etc.

- Relievers of fire risk: Those for whom the natural environment, and specifically the forest environment, is paramount.

Yet, what role does society play in forest fires? The responsiveness of citizens to an emergency depends largely on their conception of risk. This also affects their support for forest management policies and actions carried out by the emergency services. In fact, although in general fires are perceived as a catastrophic and random element, there are two underlying and coexistent stances about this assertion [23]:

- The fire as a threat to fight against: This attitude prevails in areas where there is a close relationship between the urban and natural environment. In this case, the perception is negative, because there is a sense of danger associated with fire; also, adverse effects, such as a loss of quality of land, vegetation, forest landscape, etc., are considered

- Fire as a land management tool: This perception is common in mountain and rural areas with the presence of an agricultural and livestock sector. This view can lead to the expansion of small fires and can cause forest fires of greater intensity and extent.

Human factors as a cause of forest fires are very relevant in Mediterranean Europe and specifically in Spain [24]. One of the most important characteristics is their randomness. Therefore, it seems particularly difficult to predict the behavior of a fire, such as where and when it will begin [25]. 
Current changes in climate, as well as changes in land use, are unfavorable aspects for forest fire risk reduction in Spain, as they affect the occurrence and intensity. An increase in episodes that exceed the capabilities of extinguishing devices is expected to become a national emergency [26].

Although wildfires, in some cases, may be favorable for the biodiversity and ecological characteristics of a given area, this can have huge economic and social costs [27]. In recent years, these costs have increased considerably in the transition zones between urban and forestry [28]. Recent studies have shown a positive correlation between fire prevention spending and the presence of private land and buildings [29]. This type of land is predominant in northern Spain, where there are large numbers of smallholdings. Specifically, the autonomous community of Galicia stands out as a forest fires benchmark in Europe. However, this is not the only negative socioeconomic characteristic present in this community. Therefore, is necessary to inquire into the reality that characterizes Galicia.

\subsection{Galicia, Social Vulnerability, and Wildfires}

According to Spanish statistics, the autonomous community of Galicia (Figure 1) has shown the highest rate of fires in Spain for the last decades [30].

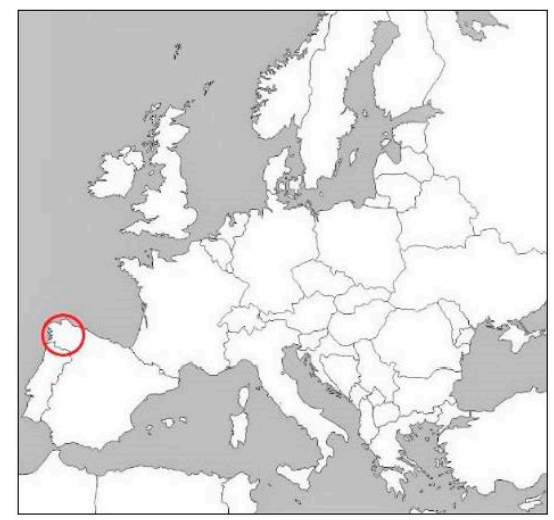

Figure 1. Situation of Gailica (Red). Own elaboration.

The objective of this paper is to establish the relationship between socioeconomic aspects that reflect the reality of the Galician municipalities and the number of forest fires from 2001 to 2015 (most recent official data available).

The first step is to establish the relevant socioeconomic variables available. For this purpose, it is paramount to have a broad knowledge of the relevant questions related to social vulnerability within a country.

Galicia has been the Spanish autonomous community most affected by forest fires since the beginning of the 21st century [31]. This can be seen in Figure 2, which compares Galicia and Spain in terms of hectares burnt and number of wildfires. In addition, recent reports show that fire seasons are lengthening and, within Europe, northern Spain and Portugal are the most critical areas [32].

Fires in Galicia have weighed significantly in Spain's general statistics. As shown in Figure 2, in certain years, both the number of wildfires occurred and burnt hectares in Galicia exceed $50 \%$ of Spanish fire disasters (Figure 3). Moreover, although the number of fires has decreased, burnt hectares follow a cyclical nature, and their mean is constant. Forest fires are known as one of the most important environmental problems in Galicia [30]. They have a far-reaching impact on the regional economy and cause greater risks for people and ecosystems, which are all linked to public spending [3].

According to specialized studies [30-35], forest fires in Galicia are directly related to a mixture of environmental-territorial plus social-economic factors. These factors can be considered well-known and predictable, but they typically exceed the capabilities of extinction means. Below, we detail the influence of both types of factors for the Galician case. 


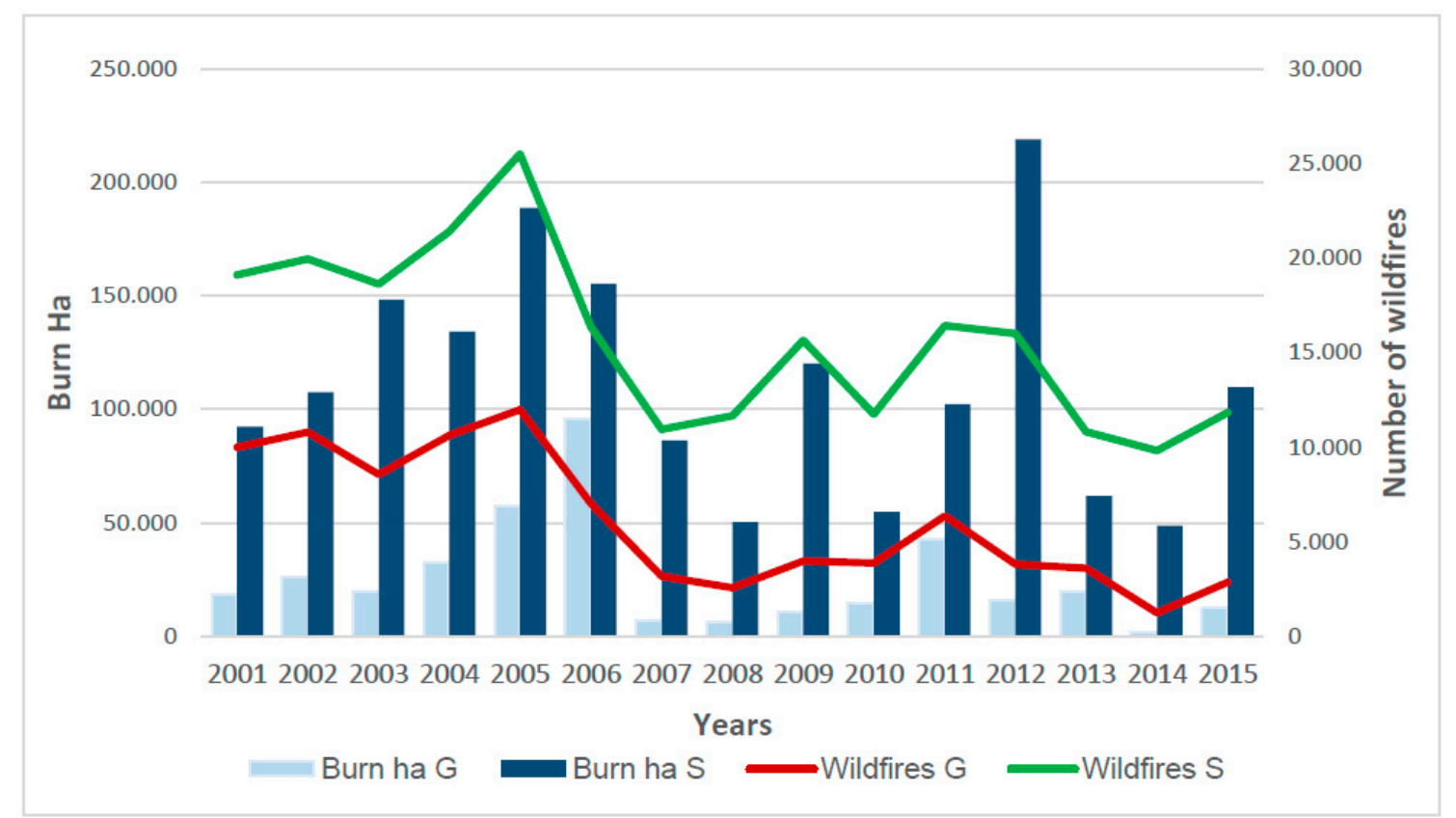

Figure 2. Relation between Galicia (G) and Spain (S). 2001-2015. Burnt hectares (ha) and number of wildfires. Source: Own elaboration from Nature Data Bank.

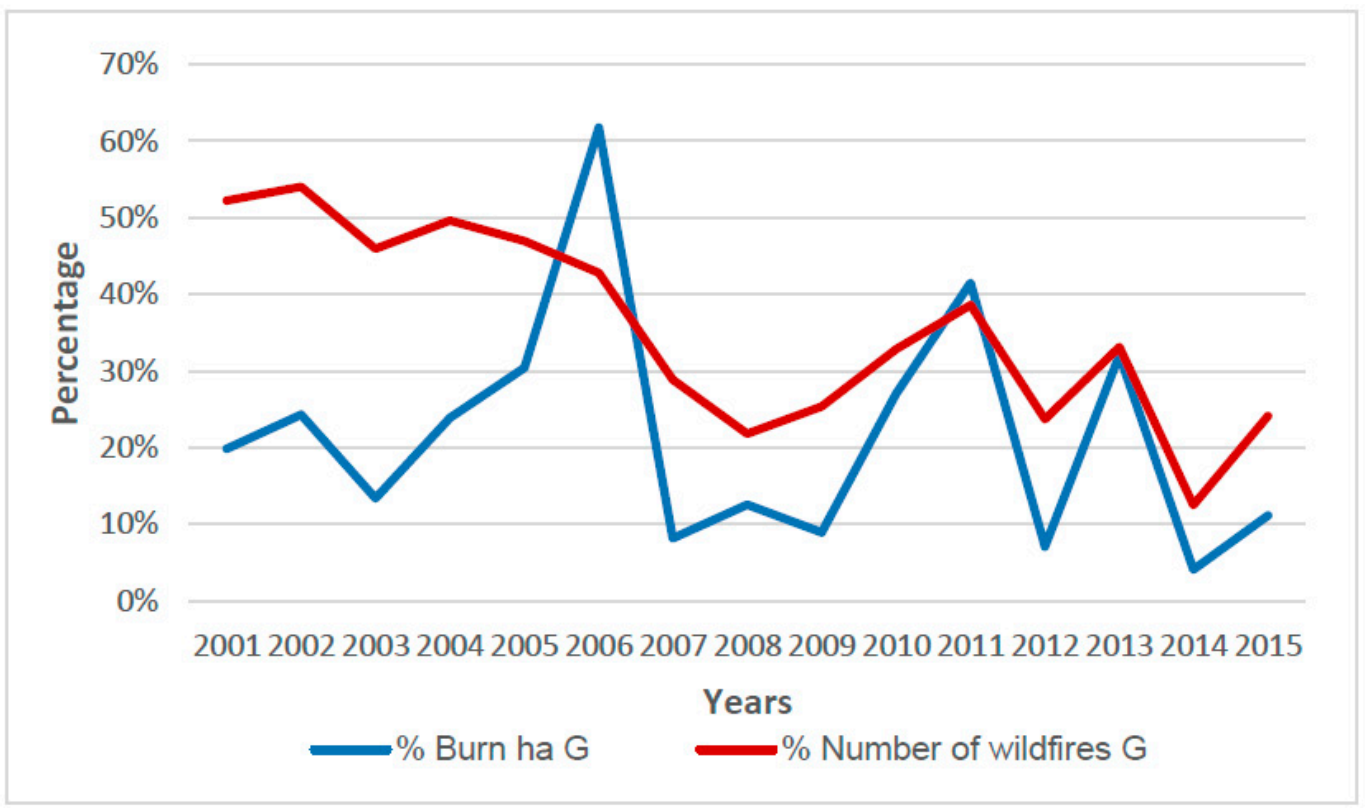

Figure 3. Burn ha and number of wildfires in Galicia in relation to Spain. 2001-2015. Source: Own elaboration from Nature Data Bank.

Environmental or territorial factors [36]:

- Deficient land management: Galicia is one of the regions with the highest vegetal production and plant growth in Spain. Galician territories have been increasing their areas with highly flammable shrubs and trees. This has been due to the lack of forest management, together with the abandonment of land used for agriculture and livestock.

- Extended livestock farming: Livestock owners make use of abandoned forest land. To acquire grass, small fires are set, increasing the chances of a huge wildfire. 
- Wastelands: They are characterized as the industrial parks, residential areas, and suburban areas of cities and towns, where shrub land and waste are mixed. They are not considered forest areas; however, they are areas where the work of extinguishing media is very intense.

- Wildland-urban interface areas: These can be defined as spaces where the surroundings of homes, neighborhoods, and urbanizations are embedded in adjacent forest areas with green spaces. They are considered high-risk areas because here, the occurrence and negligence in fire management multiply. There are large numbers of population centers with these characteristics and a higher risk of fires [37].

- Fire as a tool: Although there are permits for controlled burns, this practice is widespread in Galicia regarding both residues and forest scrub. This practice is very common in depressed and aged areas.

The above territorial factors are bound to the predominant types of land in Galicia and accordingly influence the fire data. In this region, lands are mostly privately ownership (97.26\%). Within these private properties, $32.77 \%$ are common lands, and the rest is another undetermined type of private ownership; therefore, many plots are abandoned or neglected. According to the Galicia Forest Plan, private property in the region is completely fragmented: the number of forest owners, is above 650,000 and the average plot size is two to three hectares [38].

The cause of forest fires in Galicia relates directly to the archaic habits in depressed areas and negligent use of fire as a management tool [30]. There is a lack of knowledge about such disasters, a lack of awareness and forest culture, and, obviously, there are economic interests associated with livestock and agricultural uses, which are at odds with land and forest management [34]. In the long term, these imbalances cause an increase in forest fires, and thus the further degradation of natural areas [39]. On the other hand, the large abandoned agriculture areas and the lack of land management in forest production have a positive side effect, insofar as they favor industry related to combating desertification and rural mountain management.

Social and Economic Factors

The Galician territory is complex; concentrated settlements are combined with other dispersed areas. Demographically and economically dynamic areas coexist with others characterized by a lack of vitality, but even within them there are some cities, headwaters of the region, which act as focal points of activity.

The rural depopulation is one of the major problems in Spain and, in particular, Galicia, where it is considered a demographic and territorial phenomenon. Indeed, the population in the region has dropped by $9.2 \%$ since 2008 . As far as the foreign population is concerned, the increase of immigrants helped mitigate rural depopulation before the economic downturn [40].

Other critical points related to the depopulation of rural areas are the aging population or population density that is so low, it doesn't permit economic development. However, imbalances in age and gender structures may be to blame [30]. Rural masculinization occurs at young ages due to a predominantly female migration, and also due to a lack of equal productive and reproductive work, which results in a search of a higher educational level and job opportunities associated with urban areas [23]. For its part, the low density presents common problems, such as aging, geographical isolation, a lack of spatial integration with other adjacent areas, bad connection and difficulty in transport, a lack of adequate social services, and lower levels of human capital and employment opportunities. All this inevitably leads to economic decline [12].

The impact of human resource losses, lack of territory development, and the inability to maintain economic activities, has not only economic, but also patrimonial and environmental impacts [30]. With regard to environmental effects, the abandonment of livestock and traditional agricultural uses represents a risk factor for natural environment conservation. This is because landscape transformations occur without control, and forest land management associated with rural areas are located mostly within individual plots [34]. 
Extensive livestock used to have an impact on the forest landscape, favoring the mosaics and reducing fuel in the mountains of Galicia [35]. The decline in extensive livestock farming that has taken place in Spain (around 30\% between 2004-2015) is thus considered an aggravating factor of forest fires [40].

The progressive abandonment of rural areas can be considered negative in the medium term, as the environmental effects, such as soil loss and exposure to erosive phenomena in large areas, are extensive [31]. In addition, a lack of forest land management occurs, increasing the risk of fire. In Galicia, traditional burning activities and the traditional use of fire in mountain management can lead to an increased fire occurrence [41].

All these factors ensure that forest fires continue to occur year after year in Galicia and the measures taken seem to be not enough to solve a problem of this magnitude. This situation reinforces the aim of investigating the relationship between socioeconomic variables and forest fires in Galicia and, specifically, uncovering which variables have greater explanatory power.

\subsection{Methodology}

As explained above, the main objective of this work is to establish the relationship between socioeconomic aspects of the Galician municipalities and the number of forest fires between 2001-2015.

To analyze this relationship, a quality dataset corresponding to Galician wildfires is required. Fire data were obtained from the Nature Data Bank, which has extensive information on fires in Spain. The data were separated into municipalities, and we had to choose which variables were more suitable for research, such as burnt hectares, type of terrain, etc. Afterwards, Galician municipalities socioeconomics data were joined, which were obtained from the IGE (Galician Statistics Institute).

Previous studies have established various time horizons: 2001-2006 [33], 2001-2009 [34], 2006 [30], and 2001-2010 [31]. In this sense, as information was available, it was decided to extend the time scope of research, selecting the updated data spanning from 2001 to 2015 . The observational unit has been set at the municipal level, as it has proven to be the most accurate when allowing display territory differences [33]; it is also the minimum territorial unit that provides precise and consistent socioeconomic information.

To establish the relationship between the occurrence of wildfires and the socioeconomic variables, the variables described in prior sections were considered (density, aging population, type of terrain, etc.), to allow observations of the actual effect of these data over wildfires, neglecting environmental issues. The reason for this is that in the case of a number of wildfires, the environmental impact, including the temperature, wind, and humidity is not as critical as in the case of burnt hectares [33].

Socioeconomic data were related to the Galician municipalities, so the number of fires and burnt hectares were pooled along with the Galicia socioeconomic data from each municipality. These data were adjusted to 15 years by the mean and median of every year for selected variables. Subsequently, they were adapted to avoid very large paths, positive asymmetries, or not constant marginal variations. Finally, to make these variables more representative and comparable, we made some transformations and produced some ratios with variables such as municipal hectares or population size. As has been mentioned above [10], the variables can be grouped into three dimensions: social (population), economic, and environmental/territorial. The following variables (Table 1) were obtained: 
Table 1. Variables: description and definition. Source: Own elaboration from the Galician Statistics Institute (IGE).

\begin{tabular}{|c|c|c|c|c|c|c|}
\hline Dimension & Variables & Min. & Max. & Average & Deviation & Description \\
\hline \multirow{6}{*}{ 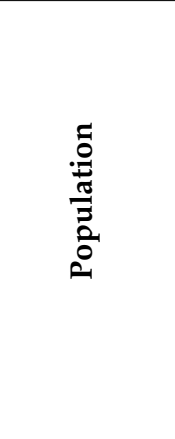 } & Population $>64$ & 76.91 & $51,034.37$ & 1932.85 & 4554.10 & Population aged over 64 years \\
\hline & Density & 0.03 & 64.61 & 1.44 & 4.26145 & Number of people per has (hectares). \\
\hline & I.replacement & 72.34 & 585.26 & 179.83 & 68.03 & $\begin{array}{l}\text { The relation among the population between } 60-64 \text { years old and the } \\
\text { population between } 15-19 \text { years old. Measures the capacity of a population to } \\
\text { replace the individuals who are retiring. }\end{array}$ \\
\hline & I.Masculinity & 83.09 & 129.83 & 96.78 & 5.89 & Relation between the number of men and women in a given population. \\
\hline & I.active & 72.40 & 177.34 & 118.78 & 19.43 & $\begin{array}{c}\text { Relation among the population between } 40-64 \text { years old and the population } \\
\text { between 15-39 years old. }\end{array}$ \\
\hline & P.Foreign & 0.00 & 2.22 & 0.03 & 0.15 & Proportion between foreign population and total population. \\
\hline \multirow{4}{*}{ 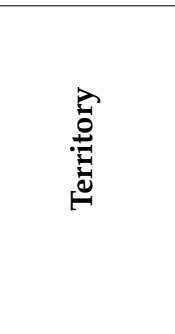 } & ParcelVal & 0.08 & 9.23 & 1.03 & 0.87 & $\begin{array}{l}\text { Value of the plots in thousands of euros divided by the number of people } \\
\text { registered in the Real Estate Cadastre. }\end{array}$ \\
\hline & DisCenter & 0.00 & 116.00 & 4.81 & 11.17 & $\begin{array}{l}\text { Buildings and dwellings of a singular entity that cannot be included in the } \\
\text { concept of nucleus divided between the set of towns with less than } 10 \\
\text { buildings, which are forming streets, squares, or other urban roads. }\end{array}$ \\
\hline & RusticHa & 0.47 & 1.00 & 0.95 & 0.07 & Rustic has by municipality. \\
\hline & Ranch & 0.00 & 0.05 & 0.01 & 0.01 & Number of livestock farms per municipality. \\
\hline \multirow{4}{*}{ 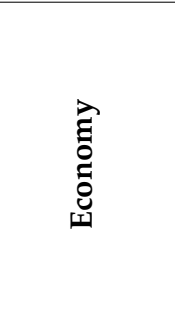 } & Livestock & 4.853 & $25,032.06$ & 3050.26 & 4501.22 & Number of cattle heads per municipality. \\
\hline & IncCap & 5915.88 & $18,777.41$ & $10,368.81$ & 1722.46 & Gross income per inhabitant. \\
\hline & Debthab & 0.00 & 0.81 & 0.19 & 0.17 & $\begin{array}{l}\text { The balance of the debt that the town councils have contracted with the bank, } \\
\text { at a certain date. The debt of the town councils was introduced, dividing it } \\
\text { among the inhabitants of each municipality so that it would be more } \\
\text { representative of the weight of each territory. }\end{array}$ \\
\hline & GDP & 2680.62 & $7,168,155.94$ & $176,090.10$ & $616,411.74$ & Gross domestic product \\
\hline
\end{tabular}


To analyze the socioeconomic variables influence in the number of wildfires in Galicia between 2001-2015, a model of multiple linear regression estimated by ordinary least squares (OLS) method was used. The observational unit was the municipality, since it was the smallest unit of information on forest fires; also, it is the minimum territorial unit where there is accurate and consistent socioeconomic information.

The model was carried out for all of the municipalities of Galicia and later for the municipalities of each province separately, in order to analyze the structural stability of the model. To determine if there were differences between provinces, the Chow test was executed [42] for the northern region (A Coruña and Lugo) and southern region (Ourense and Pontevedra). The same test was set within each region to compare each pair of provinces. The results are the following:

\section{General Model:}

The null hypothesis is that there is structural stability between north and south Galicia; the Chow contrast of a structural difference from north and south yielded a value of the statistic test. F $(15,284)$ $=7.20223 p$-value 0.0000 , so the null hypothesis is REJECTED, and therefore, there exists a structural difference between the north and south.

We proceed to see if there are structural differences within the north provinces (A Coruña and Lugo) and south provinces (Ourense and Pontevedra):

\section{North Model:}

Chow contrast for the structural difference in the North Model

$\mathrm{F}(15,130)=1.32671 p 0.1952$ value

Not reject the null hypothesis; therefore, no structural difference between the two northern provinces.

\section{South Model:}

Chow contrast for the structural difference in the South Model

$\mathrm{F}(15,124)=0.948374 p$-value 0.5135

Not reject the null hypothesis; therefore, no structural difference between the two southern provinces.

Moreover, to solve the heteroscedasticity problems presented in the model, robust standard deviations were used. To avoid other problems (variables with a large range of variation and/or skewness to the right, or not constant marginal effects), logarithms were taken when it was necessary.

\section{Results}

Model specification to explain the impact of the selected variables in the number of wildfires that occurred in Galician municipalities between 2001-2015 is:

$$
\begin{aligned}
\text { Number of Wildfires }= & \beta_{0} \\
& +\beta_{1} \text { LnPopulation }>64+\beta_{2} \text { LnDensity }+\beta_{3} \text { IncCap }+\beta_{4} \text { I.Masculinity } \\
& +\beta_{5} \text { I.active }+\beta_{6} \text { LnP.Foreign }+\beta_{7} \text { LnParcelVal }+\beta_{8} \text { LnDisCenter } \\
& +\beta_{9} \text { LnRanch }+\beta_{10} \text { LnRusticHa }+\beta_{11} \text { LnGDP }+\beta_{12} \text { LnLivestock } \\
& +\beta_{13} \text { I.replacement }+\beta_{14} \text { LnDebtHab }+\epsilon
\end{aligned}
$$

The obtained results for each model are shown in Table 2. For the General Model, the variables that show a negative relationship with the number of wildfires are density, per-capita gross income, active population index, plot value, and the relation between lone buildings and nucleus. In the same way, the population over age 64, masculinity index, and proportion of foreigners have a positive relationship with the number of wildfires. For the North Model, the variables per-capita gross income and the relation between lone buildings and nucleus show a negative relationship with the number of wildfires, while the population over 64 and gross domestic product (GDP) have a positive relationship. Finally, in the South Model, wildfires show a negative relationship with density and active population index, and a positive relationship with the population over 64 and the masculinity index. 
Table 2. Empirical results of the model. Dependent variable: number of wildfires.

\begin{tabular}{|c|c|c|c|c|c|c|}
\hline \multirow{2}{*}{$\begin{array}{c}\text { Independent } \\
\text { Variables }\end{array}$} & \multicolumn{2}{|c|}{ General Model } & \multicolumn{2}{|c|}{ North Model } & \multicolumn{2}{|c|}{ South Model } \\
\hline & $\begin{array}{c}\text { Coefficients } \\
(\beta)\end{array}$ & $p$ Value & $\begin{array}{c}\text { Coefficients } \\
(\beta)\end{array}$ & $p$ Value & $\begin{array}{c}\text { Coefficients } \\
(\beta)\end{array}$ & $p$ Value \\
\hline Constant & -931.816 & 0.002 & -1207.57 & 0.000 & -1750.38 & 0.000 \\
\hline LnPopulation $>64$ & $189.671^{* * *}$ & 0.000 & $132.692^{* * *}$ & 0.000 & $273.830 * * *$ & 0.000 \\
\hline LnDensity & $-212.140^{* * *}$ & 0.000 & -19.9101 & 0.573 & $-273.462 * * *$ & 0.000 \\
\hline IncCap & $-0.0584683^{* * *}$ & 0.000 & $-0.0394832 * * *$ & 0.000 & -0.0223893 & 0.264 \\
\hline I.Masculinity & $5.68822 * *$ & 0.010 & 1.71407 & 0.369 & $13.1212^{* * *}$ & 0.000 \\
\hline I.active & -3.11713 * & 0.051 & -1.26194 & 0.384 & $-3.55956^{*}$ & 0.079 \\
\hline LnP.Foreign & $53.7118^{* * *}$ & 0.002 & -12.8223 & 0.291 & 50.9607 & 0.121 \\
\hline LnParcelVal & $-60.4937^{* * *}$ & 0.001 & 4.24432 & 0.850 & -36.5176 & 0.194 \\
\hline LnDisCenter & $-30.7492^{* * *}$ & 0.001 & $-14.9480 *$ & 0.063 & 15.6403 & 0.379 \\
\hline LnRanch & 35.4466 & 0.138 & -21.3153 & 0.527 & 33.6097 & 0.158 \\
\hline LnRusticHa & -275.325 & 0.119 & 95.0943 & 0.659 & -223.834 & 0.114 \\
\hline LnGDP & 52.6489 & 0.119 & $46.6009 * *$ & 0.011 & -17.6842 & 0.766 \\
\hline LnLivestock & -2.94676 & 0.846 & 27.7159 & 0.194 & 10.2266 & 0.546 \\
\hline I.replacement & 0.108139 & 0.714 & -0.0719371 & 0.863 & -0.207825 & 0.523 \\
\hline LnDebtHab & 27.3305 & 0.676 & 47.9772 & 0.549 & -2.70796 & 0.972 \\
\hline $\mathbf{R}^{2}$ & \multicolumn{2}{|l|}{0.421} & \multicolumn{2}{|l|}{0.547} & \multicolumn{2}{|c|}{0.501} \\
\hline Sample size & \multicolumn{2}{|l|}{314} & \multicolumn{2}{|l|}{160} & \multicolumn{2}{|c|}{154} \\
\hline
\end{tabular}

\section{Discussion}

Table 2 shows the three models for the whole region (General Model), the north, and the south of Galicia. Thus, the differences in significance for each different model can be displayed.

The $\mathrm{R}^{2}$ values of the models can be considered representative, because a high predictive ability of the dependent variable in the General, North, and South models is achieved $(42.1 \%, 54.7 \%$, and $50.1 \%$, respectively). Therefore, the number of forest wildfires in Galicia has a high relationship with the socioeconomic variables that characterize the municipalities of this community, as the estimated models together are significant.

The only variable that keeps the significance at $1 \%$ in the three models is the "population over 64 years old", so it is one of the most explanatory variables of forest fires in Galicia.

The variables "population density" and "gross income per capita" are also significant at $1 \%$ for two of the models (the South and General models in the case of the "population density", and the North and General models in the case of "gross income per capita").

The "index of masculinity", meanwhile, is significant at 1\% in the South Model, and at 5\% in the General Model.

The "proportion of the assessed value by cadastral holder", the "proportion of scattered/core", and the "proportion of foreign" are only significant at $1 \%$ in the case of the General Model, while the "proportion of scattered/core" is $10 \%$ in North Model.

When analyzing the coefficients $(\beta)$ sign, the relations, direct or inverse, with the dependent variable, the "number of wildfires", are the same for all three models. More details are set out below:

- There is an inverse relationship among "density", "gross income per capita," the "active population index", the "plot value per holder", and the "proportion of scattered/cores", indicating that the lower the value of these variables, the greater the number of wildfires. In the case of the "active population index", if the value decreases, it means a more aged population. In the case of property value, a decrease means that the plots are less valuable. As to the ratio "scattered/cores", a decrease in its value shows that there are fewer scattered areas and subsequently more wildfires; this is related to the forestry-urban interface fields (transition lands) associated with population centers. 
- The relationship is direct to "population over 64 years," which clearly shows that there are more wildfires within aging population environments; this relies on burning-land traditions and cultural habits, a lower level of education and, in particular, a higher vulnerability. These territories also present a higher "masculinity index", since there has been a historical female abandonment of rural areas; as a result, the population density is lower. The positive association between wildfire numbers and the rate of foreign population could be connected with their higher presence in vulnerable areas with lower incomes, precarious services, exclusion factors, etc. A positive GDP ratio (higher GDP, means more wildfires) would be explained by the existence of a larger number of urban cores. This means higher municipality richness, and consequently, the existence of more forestry-urban interface, and a higher likelihood of wildfires.

These data show clear differences between the North and South models. So, a lesson to learn is that the fire-fighting actions that are to be carried out must be different depending on the municipality geographical location. While in the north, the economic aspects should be more considered in more depth, in the south, it would be necessary to delve into the social and demographic aspects. Indeed, this does not mean that all of the community problems cannot be solved with community activities.

Within the population and social variables, the strong positive relationship between the aging population and the increasing number of wildfires is remarkable, as is the strong negative relationship between density and wildfires: the lower the population, more wildfires occur because of an abandonment of the territory. These two variables together reflect that depressed areas, with higher aging rates, produce higher number of wildfires. In these areas, there is also a greater number of foreigners with fewer resources and lower incomes. In addition, a reduction in the cadastral value of plots occasions an abandonment of land, which in turn favors the number of fires.

\section{Conclusions}

The object of this paper is to establish the relationship between socioeconomic aspects that reflect the reality of the Galician municipalities and the number of forest fires between 2001-2015. The ultimate goal of our work is to identify those socioeconomic issues for achieving a greater impact on prevention actions.

At this point, the most explanatory variables in our model are an aged population and low population density; the community actions of the competent authorities should take into account the negative connotation of both variables on the intervention action planning. This is difficult in the short term, but a greater impact on improving rural life quality in these areas predictably would alter these variables positively toward their relation to forest fires. By promoting the participation and improvement of education, the variables that influence the occurrence of wildfires could be modified, changing the beliefs and activities linked to aged populations with lower levels of education. The need to establish models of sustainable development is detected, taking into account the social aspects that stand out as a cause of forest wildfires.

Regarding those dimensions related to the territory, the use of biomass has been carried out in Galicia, but the design of criteria that guarantee their sustainability still remains open. Avoiding ground affections and competition with other sectors such as livestock and agriculture would also help give value to the forest. These measures would help increase the plots' cadastral value and, as shown by the results, would lower the occurrence of wildfires. Synergies should be encountered between agroforestry mosaics systems and holding investments. All of these measures are ultimately targeted to the quality improvement of life in rural areas, influencing variables such as population density and income per capita. Adding value to the land would help people change their perception of forest resources, and therefore could reduce wildfires.

Looking not to lose the forest value, a priority is to increase spending on prevention and elaborate long-term strategies. It is also necessary to restore damaged areas to prevent further deterioration in later adverse environmental conditions. The most efficient way to maintain economic, social, and environmental functions of an area is through trying to emphasize their importance before the 
occurrence of an event. By including social variables as a cause of the wildfires, authorities can insist on reducing these. It is important to emphasize the most meaningful variables related to wildfire production and carry out actions designed for their reduction (for instance, managing the wildland-urban interface areas, which are related to variables such as the ratio scattered/cores and GDP). It is also important to improve working conditions for women in rural areas, in order to reduce the masculinity index, and therefore increase the population density.

The works carried out on prevention and extinction are the responsibility of public institutions. Although in Spain, the central government is responsible for basic legislation and public policy design, competences have been transferred to the autonomous communities. It is necessary to involve local bodies for the better management of natural hazards and specifically for forest wildfires, taking into account the socioeconomic variables that affect each. Therefore, it is important to establish the differences between existing social groups in a given area, analyze the exposure and risk involved, and educate these social groups. As it has been seen throughout the study, it is important to take into account the differences between northern and southern Galicia, working on the most important variables in each area. This will ensure that the actions are more efficient and better results against wildfires are achieved.

Changes should be planned for the mid-long term, promoting interactions between different population sections and age cohorts directed to influence certain harmful traditional behaviors associated with aging societies. This would make it possible to improve the labor force turnover rate and demographic structure. One of the great pending challenges is to establish unity among all the factors involved in a wildfire, from prevention to extinction, understanding their behavior and minimizing their effects.

The relevance of the findings of this paper, which establish a relationship between socioeconomic variables and the number of wildfires, must be considered by technical authorities and policymakers. It is not only necessary to act on climate, environmental, and natural issues when it comes to reducing the risk of occurrence. Actions must also affect all of the aspects that influence the risk of occurrence. Authorities must develop strategies that are complementary to prevention efforts, where these variables representing social vulnerability (such as aspects of exclusion, low income, or aging) are mitigated. The existing research shows this relationship, and therefore highlights an existing problem in society. Its severity can be reduced through strategies and policies that will have their effect in the long and mid-term.

In short, we have demonstrated the influence of social variables on the production of wildfire. Therefore, by working on these issues, the occurrence of anthropogenic wildfires could be reduced.

\section{Future Research Lines and Limitations}

The main limitation of the research is related to the data. Some very important variables in the socioeconomic sphere have not been selected because of the difficulty of obtaining them at the municipal level. In addition, it is very difficult to obtain prevention and extinction spending data, even making a request to different Galician agencies. We should also mention that another limitation comes from the inability of the model to predict indirect relationships between variables, although this leads us directly into the future course of our investigation.

In order to deepen the relations established between socioeconomic variables and forest fires, a structural equation model (SEM) will be elaborated. This is a multivariate statistical technique for testing and estimating causal relationships from statistical data. SEM allows drawing qualitative assumptions on causality, developing different constructs by the data. The behaviors of the variables in the linear regression deserve to be studied more precisely. It is necessary to establish the intensity of relations, their direction, and more importantly, establish direct and indirect correlations between variables, in order to create constructs. These constructs will be composed of interrelated economic, climatological, environmental, or social variables. We propose a more precise way to study social 
vulnerability and its effect on forest fires, and investigate whether reducing vulnerability in all its components can reduce the risk of wildfire more efficiently.

Author Contributions: All the author of this article has contributed in the elaboration and designing of the model. They also collaborate in the writing of the main body of the paper.

Funding: This research was funded by Fundación AON España (http:/ / fundacionaon.es/).

Conflicts of Interest: The authors declare no conflict of interest.

\section{References}

1. Ager, A.; Evers, C.; Day, M.; Preisler, H.; Barros, A.; Nielsen-Pincus, M. Network analysis of wildfire transmission and implications for risk governance. PLoS ONE 2017, 12, e0172867. [CrossRef] [PubMed]

2. Haynes, K.; Handmer, J.; Mcaneney, J.; Tibbits, A.; Coates, L. Australian bushfire fatalities 1900-2008: Exploring trends in relation to the 'Prepare, stay and defend or leave early' policy. Environ. Sci. Policy 2010, 13, 185-194. [CrossRef]

3. Hernández, L. Dónde arden nuestros bosques. Análisis y Soluciones de WWF 2016, 1, 64. Available online: http:/ / awsassets.wwf.es/downloads/dondeardennuestrosbosques2016.pdf (accessed on 22 April 2018).

4. Padilla, M.; Vega-García, C. On the comparative importance of fire danger rating indices and their integration with spatial and temporal variables for predicting daily human-caused fire occurrences in Spain. Int. J. Wildland Fire 2011, 20, 46-58. [CrossRef]

5. Kocher, S.; Butsic, V. Governance of Land Use Planning to Reduce Fire Risk to Homes Mediterranean France and California. Land 2017, 6, 24. [CrossRef]

6. Murphy, B. Enhancing Local Level Emergency Management: The Influence of Disaster Experience and the Role of Households and Neighborhoods; ICLR Research: Toronto, ON, Canada, 2005.

7. Ley 43/2003, de 21 de noviembre, de Montes. BOE» núm. 280, de 22/11/2003. BOE-A-2003-21339. Available online: https:/ / www.boe.es/eli/es/1/2003/11/21/43/con (accessed on 16 May 2018).

8. Bentley, P.D.; Penman, T.D. Is there an inherent conflict in managing fire for people and conservation? Int. J. Wildland Fire 2017, 26, 455. [CrossRef]

9. Del Moral Ituarte, L.; Pita López, M.F. El papel de los riesgos en las sociedades contemporáneas. In Riesgos Naturales; Ayala-Carcedo, F.J., Olcina Cantos, J., Eds.; ARIEL: Barcelona, Spain, 2002; pp. 75-86.

10. Birkmann, J. Measuring Vulnerability to Natural Hazards: Towards Disaster Resilient Societies, 2nd ed.; United Nation University Press: Tokyo, Japan; New York, NY, USA, 2013.

11. Donner, W.; Rodríguez, H. Population Composition, Migration and Inequality: The Influence of Demographic Changes on Disaster Risk and Vulnerability. Soc. Forces 2008, 87, 1089-1114. [CrossRef]

12. Bergstrand, K.; Mayer, B.; Brumback, B.; Zhang, Y. Assessing the Relationship between Social Vulnerability and Community Resilience to Hazards. Soc. Indic. Res. 2015, 122, 391-409. [CrossRef] [PubMed]

13. Ashe, B.; Mcaneney, K.J.; Pitman, A.J. Total cost of fire in Australia. J. Risk Res. 2009, 12, 121-136. [CrossRef]

14. Elliott, J.R.; Pais, J. When Nature Pushes Back: Environmental Impact and the Spatial Redistribution of Socially Vulnerable Populations. Soc. Sci. Q. 2010, 91, 1187-1202. [CrossRef]

15. Molina, J.; Rodríguez, Y.; Silva, F.; Herrera, M. Economic vulnerability of fire-prone landscapes in protected natural areas: Application in a Mediterranean Natural Park. Eur. J. For. Res. 2017, 136, 609-624. [CrossRef]

16. Iyalomhe, F. Understanding developing countries vulnerability and adaptation to climate change using theoretical change vulnerability framework. Afr. J. Comput. ICT 2011, 4, 33-40.

17. Sharma, S.; Pant, H. Vulnerability of Indian Central Himalayan Forests to Fire in a Warming Climate and a Participatory Preparedness Approach Based on Modern Tools. Curr. Sci. 2017, 112, 2100. [CrossRef]

18. Cirella, G.T.; Iyalomhe, F.O.; Russo, A. Vulnerability and risks related to climatic events in urban coastal environments: Overview of actuality and challenges of methodologies and approaches. J. Urban Plan. Landsc. Environ. Des. 2016, 1, 67.

19. Wisner, B.; Blaikie, P.; Cannon, T.; Davis, I. At Risk: Natural Hazards, People's Vulnerability and Disasters, 2nd ed.; Routledge: New York, NY, USA, 2004; 471p, ISBN 0415-252164.

20. Morrow, B.H. Identifying 3nd Mapping Community Vulnerability. Disasters 1999, 23, 1-18. [CrossRef]

21. Fogel, S.J. Reducing Vulnerability for Those Who Are Homeless during Natural Disasters. J. Poverty 2017, 21, 208. [CrossRef] 
22. Alonso Climent, I. Tercer mundo, desarrollo, desastres y tecnología. Una mirada desde la geografía. Ser. Geográfica 2002, 10, 11-26.

23. Ballart, H.; Vázquez, I.; Chauvin, S.; Gladine, J.; Plana, E.; Font, M.; Serra, M. La comunicación del riesgo de incendios forestales. Recomendaciones operativas para mejorar la prevención social; Projecte eFIRECOM (DG ECHO 2014/PREV /13); Ediciones CTFC: Boadilla del Monte, Spain, 2016; 30p.

24. Martínez-Fernández, J.; Chuvieco, E.; Koutsias, N. Modelling long-term fire occurrence factors in spain by accounting for local variations with geographically weighted regression. Nat. Hazards Earth Syst. Sci. 2013, 13, 311-327. [CrossRef]

25. Paveglio, T.B.; Edgeley, C.M.; Stasiewicz, A.M. Assessing influences on social vulnerability to wildfire using surveys, spatial data and wildfire simulations. J. Environ. Manag. 2018, 213, 425-439. [CrossRef]

26. Moreno, J.M. Evaluación Preliminar de los Impactos en España por Efecto del Cambio Climático. Boletín CF+S 38/39. 2014. Available online: http://polired.upm.es/index.php/boletincfs/article/view/2617/2683 (accessed on 11 September 2018).

27. Crompton, R.; Mcaneney, J.; Chen, K.; Pielke, R.; Haynes, K. Influence of Location, Population, and Climate on Building Damage and Fatalities due to Australian Bushfire. Weather. Soc. 2010, 2, 300-310. [CrossRef]

28. Bouillon, C.; Fernandez Ramiro, M.M.; Sirca, C.; Fierro Garcia, B.; Casula, F.; Vila, B.; Long Fournel, M.; Pellizzaro, G.; Arca, B.; Tedim, F.; et al. A tool for mapping rural-urban interfaces on different scales. Adv. For. Fire Res. 2014. [CrossRef]

29. Stein, S.M.; Menakis, J.; Carr, M.A.; Comas, S.J.; Stewart, S.I.; Cleveland, H.; Bramwell, L.; Radeloff, V.C. Wildfire, Wildlands, and People: Understanding and Preparing for Wildfire in the Wildland-Urban Interface-A Forests on the Edge Report; Gen. Tech. Rep. RMRS-GTR-299; Department of Agriculture, Forest Service, Rocky Mountain Research Station: Fort Collins, CO, USA, 2013; 36p.

30. Balsa Barreiro, J.; Hermosilla, T. Socio-geographic analysis of the causes of the 2006's wildfires in Galicia (Spain). For. Syst. 2013, 22, 497-509. [CrossRef]

31. Loureiro, M.; Barreal, J. Modelling spatial patterns and temporal trends of wildfires in Galicia (NW Spain). For. Syst. 2015, 24, e022. [CrossRef]

32. San-Miguel-Ayanz, J.; Durrant, T.; Boca, R.; Libertà, G.; Branco, A.; de Rigo, D.; Ferrari, D.; Maianti, P.; Artés, T.; Costa, H.; et al. Forest Fires in Europe, Middle East and North Africa 2017; EUR 29318 EN; Publications Office of the European Union: Luxembourg, 2018; ISBN 978-92-79-92831-4. [CrossRef]

33. Barreal, J.; Loureiro, M.; Picos, J. Estudio de la incidencia de los incendios en Galicia: Una perspectiva socioeconómica. Revista Galega de Economía 2011, 20. Available online: https:/ / www.redalyc.org/comocitar. oa?id=39121275013 (accessed on 14 March 2018).

34. Rigueiro, A.; Mosquera, M.R.; López, L.; Pastor, J.C.; González, M.P.; Romero, R.; Villarino, J.J. Reducción del riesgo de incendios forestales mediante el pastoreo del caballo gallego de monte. Cuadernos de la Sociedad Española de Ciencia Forestal 2002, 14, 115-118.

35. Barreal, J.; Loureiro, M.; Picos, J. Estudio de la causalidad de los incendios forestales en Galicia. Economia Agraria y Recursos Naturales 2012, 12, 101-116. [CrossRef]

36. COSE Selvicultores. Informe: El problema actual de los incendios forestales en Galicia. Informe de la Confederación de Organizaciones de Selvicultores de España 2015, 1, 40. Available online: https://studylib. es/doc/6173943/informe-\%E2\%80\%9Cel-problema-actual-de-los-incendios-forestales-en (accessed on 5 April 2018).

37. Galiana Martín, L. Las interfaces urbano-forestales: Un nuevo territorio de riesgo en España. Boletín de la Asociación de Geógrafos Españoles 2012, 58, 205-226. [CrossRef]

38. PLADIGA 2018. Memoria. Plan de Prevención e Defensa Contra os Incendios Forestais de Galicia; Xunta de Galicia, Consellería do Medio Rural: Santiago, Spain, 2018.

39. Vilariño, J.P. Desarrollo corporativo del sector forestal. Agricultura y Sociedad 1998, 85, 15-42.

40. Consejo Económico y Social (CES). Informe 01/2018, El medio rural y su vertebración social y territorial; Consejo Económico y Social: Madrid, Spain, 2018; Número 01; ISBN 978-84-8188-374-9. 
41. Wigtil, G.; Hammer, R.B.; Kline, J.D.; Mockrin, M.H.; Stewart, S.I.; Roper, D.; Radeloff, V.C. Places where wildfire potential and social vulnerability coincide in the coterminous United States. Int. J. Wildland Fire 2016, 25, 896. [CrossRef]

42. Fisher, F.M. Tests of equality between sets of coefficients in two linear regressions. Econometrica 1970, 38, 361-366. [CrossRef] 